\title{
PENGELOLAAN WAKAF PRODUKTIF DALAM BENTUK SPBU STUDI KASUS SPBU MASJID AGUNG SEMARANG
}

\author{
Nurodin Usman \\ Universitas Muhammadiyah Magelang \\ Nurodin_2000@yahoo.com
}

\begin{abstract}
Abstrak
Ada beberapa varian model pengelolaan dan pengembangan bandha wakaf yang menggabungkan konsep wakaf produktif dan wakaf langsung (konsumtif). Di antara bentuk pengelolaan dan pengembangan bandha wakaf produktif tersebut diwujudkan dalam bentuk Stasiun Pengisian Bahan Bakar Umum (SPBU). Penelitian ini merupakan penelitian kualitatif deskriptif yang bertujuan mendeskripsikan pengelolaan dan pengembangan bandha wakaf Masjid Agung Semarang yang memiliki lahan wakaf seluas 119,1270 Hektar, khususnya yang dikelola untuk SPBU. Hasil penelitian menunjukkan bahwa SPBU Masjid Agung Semarang telah berhasil mewujudkan model pengelolaan dan pengembangan aset wakaf secara produktif. SPBU Masjid Agung Semarang telah berhasil memberikan kontribusi yang signifikan bagi Masjid Agung Semarang dan mampu memberikan layanan yang baik bagi konsumen, karena menyediakan bahan bakar minyak yang diperlukan oleh pengendara pada umumnya. SPBU Masjid Agung Semarang juga sudah dilengkapi dengan berbagai fasilitas, seperti mushalla, toilet, pengisian air dan angin, ATM, tempat istirahat, minimarket, klinik, usaha cuci mobil, dan penjualan oli.
\end{abstract}

Kata kunci: bandha wakaf, SPBU, wakaf produktif, wakaf konsumtif. 


\begin{abstract}
There are several variants of the management and development models that incorporate the concept of waqf productive and consumptive waqf. In the form of management and development of productive waqf property is manifested in the form of public refueling station (SPBU). This research is a descriptive qualitative study aimed to describe the management and development of waqf property of the Great Mosque of Semarang, which has an area of 119.1270 hectares of waqf land, particularly those managed to SPBU. The results showed that SPBU of Great Mosque of Semarang has succeeded in realizing the asset management model and the development of the productive waqf. SPBU of Great Mosque of Semarang have managed to make a significant contribution to the Great Mosque of Semarang and able to provide good service for consumers, as it provides the fuel needed by motorists generally. SPBU of Great Mosque of Semarang is also equipped with various facilities, such as prayer rooms, toilets, filling water and aeration, ATM, rest area, minimarket, clinic, car wash business, and the sale of oil .
\end{abstract}

Keywords: Waqf property, SPBU, productive waqf, consumptive waqf.

\title{
Pendahuluan
}

Tradisi mewakafkan tanah untuk masjid telah berlangsung semenjak zaman dahulu dan terus berkembang hingga saat ini. Kegiatan masjid juga berkembang seiring dengan kondisi masyarakat di sekitarnya. Masjid-masjid yang berdiri di tempat strategis dan didukung sumber dana yang memadai mampu mewujudkan serangkaian program kegiatan yang tidak hanya berkaitan dengan ibadah mahdah, melainkan juga berdimensi pemberdayaan.

Di antara masjid yang memiliki aset wakaf cukup besar adalah Masjid Agung Semarang (MAS). Aset wakaf masjid ini, yang biasa disebut bandha wakaf Masjid Agung Semarang, berupa tanah yang diberikan oleh Ki Ageng Pandan Arang yang merupakan pendiri sekaligus bupati pertama kota Semarang. Menurut Fathuddin (2000: 7), sejak zaman kesultanan Demak, Masjid Agung Semarang telah memiliki kekayaan berupa tanah yang cukup luas yang semula disediakan sebagai upah untuk digarap para merbot dan sebagian lagi untuk biaya pemeliharaan masjid itu sendiri. 
Dari data kekayaan BKM tahun 2005, diketahui bahwa total luas tanah bandha wakaf Masjid Agung Semarang setelah proses ruislag adalah 1.316.733 $\mathrm{m}^{2}$ tersebar di Kabupaten Demak $\left(675.717 \mathrm{~m}^{2}\right)$, Kabupaten Kendal $\left(12.200 \mathrm{~m}^{2}\right)$, Kota Semarang $\left(628.856 \mathrm{~m}^{2}\right)$. Aset-aset wakaf tersebut telah berhasil dikelola dan dikembangkan dalam beberapa varian model yang menggabungkan konsep wakaf produktif dan wakaf langsung (konsumtif). Di antara bentuk pengelolaan dan pengembangan bandha wakaf tersebut diwujudkan dalam bentuk Stasiun Pengisian Bahan Bakar Umum (SPBU) yang saat ini dikenal dengan istilah SPBU Masjid Agung Semarang.

\section{Rumusan Masalah}

Berdasarkan uraian di atas, penelitian ini bermaksud mendeskripsikan model pengelolaan dan pengembangan bandha wakaf Masjid Agung Semarang dalam bidang unit usaha produktif seperti di atas. Pertanyaan dalam penelitian ini adalah bagaimana pengelolaan dan pengembangan bandha wakaf Masjid Agung Semarang dalam bentuk Stasiun Pengisian Bahan Bakar Umum (SPBU) Masjid Agung Semarang yang terletak di Jalan Arteri Soekarno-Hatta Kota Semarang?

\section{Metode Penelitian}

Penelitian ini merupakan penelitian lapangan yang bertujuan mendeskripsikan dan merumuskan model pengelolaan dan pengembangan bandha wakaf. Pendekatan yang dipakai adalah pendekatan manajemen. Menurut Putra (2013: 102), penelitian kualitatif manajemen dilakukan untuk menggali makna yang dihayati oleh para pengelola (manajer) dalam menjalankan fungsi-fungsi manajemen, proses-proses dalam pengambilan keputusan, sistem pengawasan, aspek kepemimpinan, dan aspek-aspek manajemen lainnya.

Teknik pengumpulan data dilakukan melalui observasi, wawancara, dan dokumentasi. Teknik observasi dilakukan untuk mengamati, mencatat, dan memotret segala sesuatu yang berkaitan dengan model pengelolaan dan pengembangan bandha wakaf. Teknik wawancara dilakukan secara terbuka terhadap 
para pengelola bandha wakaf untuk menggali berbagai macam informasi yang berkaitan dengan model pengelolaan dan pengembangan bandha wakaf. Sejumlah informan kunci yang berhasil diwawancarai adalah Hasan Toha Putra selaku Ketua Badan Pengelola Masjid Agung Semarang, Wahid Ahmad selaku Badan Pengelola Masjid Agung Semarang, Fery Pujiyanto selaku Manajer SPBU Masjid Agung Semarang, dan Arifin selaku Anggota Badan Kesejahteraan Masjid Agung Semarang. Teknik dokumentasi dilakukan untuk mengungkap data-data yang tersimpan dalam dokumen, untuk menggali data-data yang tidak dapat diperoleh melalui observasi dan wawancara, atau untuk melengkapi dan memperkuat data-data yang diperoleh dari penggunaan teknik observasi dan wawancara.

Analisis data dilakukan dengan teknik analisis deskriptif kualitatif. Proses analisis dilakukan untuk memahami, menelaah, mendalami, dan menginterpretasikan fenomena yang muncul terkait aktifitas pengelolaan dan pengembangan bandha wakaf. Dalam penelitian ini, peneliti menggunakan teori tata kelola wakaf produktif dalam bidang kesehatan untuk membantu peneliti dalam menganalisis data yang menjadi obyek penelitian. Proses analisis data dilakukan melalui serangkaian aktifitas yang saling berkaitan, yaitu reduksi data, penyajian data, dan penarikan kesimpulan (Emir, 2012: 129).

\section{Tata Kelola Wakaf}

Tata kelola merupakan terjemahan dari kata governance. Tata kelola yang baik mengandung arti keterlibatan aktif dari pihak-pihak terkait, transparansi, bertanggung jawab, efektif, adil, menjamin adanya supremasi hukum, menjamin bahwa prioritas politik, sosial, dan ekonomi, serta memperhatikan kepentingan mereka yang paling miskin dan lemah dalam proses pengambilan keputusan menyangkut alokasi sumber daya pembangunan (Sedarmayanti, 2007: 3).

Kata wakaf, secara etimologis, berasal dari "waqafa" yang berarti "habasa". Dalam kamus Lisan al- 'Arab, (Ibn Manzur, t.th.: 6/44) kalimat "habasahu” berarti "dia telah menahanannya". Menurut Qahaf (2006: 55), kata "waqf" dan "habs" berarti menahan sesuatu dari konsumsi dan melarang seluruh manfaat atau keuntungan dari selain pihak yang menjadi sasaran wakaf. 
Dalam istilah fikih, terdapat perbedaan mengenai rumusan definisi wakaf. Sebagian perbedaan ini bersifat redaksional dan sebagian lainnya berkaitan dengan pandangan mereka mengenai hukum wakaf, seperti syarat harta yang boleh diwakafkan, sifat wakaf apakah langgeng atau sementara, dan prinsip wakaf yang berkaitan dengan pemindahan hak milik (lazim) atau tidak (gair lazim).

Nazih Hammad (1995: 353) mendefinisikan wakaf sebagai akad menahan aset wakaf dan menyalurkan manfaatnya pada sabilillah. Munzir Qahaf (2006: 62) mendefinisikan wakaf yaitu akad menahan harta, baik bersifat selamanya maupun jangka waktu tertentu, untuk diambil manfaatnya secara berulangulang, dari harta tersebut atau dari hasilnya, untuk keperluan kebaikan, baik yang bersifat umum maupun khusus.

Dalam Undang-Undang Nomor 41 Tahun 2004, wakaf diartikan dengan perbuatan hukum wakif untuk memisahkan dan/atau menyerahkan sebagian harta benda miliknya untuk dimanfaatkan selamanya atau untuk jangka waktu tertentu sesuai dengan kepentingannya guna keperluan ibadah dan/atau kesejahteraan umum menurut syariah.

Mengenai dasar hukum wakaf, secara umum tidak ditemukan ayat dalam Alquran yang menerangkan hukum wakaf secara detail. Dalil-dalil dari Alquran yang dijadikan sebagai dasar bagi disyariatkannya wakaf adalah ayat-ayat yang menjelaskan tentang infaq $f i$ sabilillah. Hal ini dapat dimaklumi mengingat wakaf merupakan bagian dari infaq fi sabilillah yang dianjurkan oleh Islam. Selain itu, ayat-ayat yang memerintahkan berbuat kebaikan atau al-khair juga dapat dijadikan dalil disyariatkannya wakaf. Kata al-khair dimaknai sebagai perbuatan yang hukumnya sunnah, termasuk wakaf.

Dalil mengenai wakaf secara lebih detail terdapat dalam hadis. Terdapat banyak hadis yang menjelaskan disyariatkannya wakaf, diantaranya kisah yang diriwayatkan Ibn 'Umar, bahwa 'Umar Ibn Khathab memperoleh tanah (kebun) di Khaibar, lalu ia datang kepada Nabi SAW, seraya berkata, "Wahai Rasulullah saya memperoleh tanah yang belum pernah saya peroleh harta yang lebih baik bagiku melebihi tanah tersebut, maka apa yang engkau perintahkan (kepadaku) mengenainya?" Nabi SAW menjawab, "Jika mau, kamu tahan pokoknya dan kamu sedekahkan (hasilnya)". Ibnu 'Umar berkata, "Maka 'Umar menyedekahkan tanah tersebut (dengan mensyaratkan) bahwa tanah itu tidak dijual, tidak dihibahkan, dan tidak diwariskan, yaitu kepada orang-orang fakir, kerabat, riqab 
(hamba sahaya), sabilillah, tamu dan ibn sabil. Tidak berdosa bagi orang yang mengelola untuk memakan dari (hasil) tanah itu secara ma'ruf (wajar) atau memberi makan seorang teman, dengan tanpa menjadikannya sebagai harta hak milik (al-'Asqalani, 2000: 5/501).

Hadis 'Umar ini adalah hadis yang paling populer dalam kajian wakaf sehingga tidak salah jika Ibnu Hajar menyebutnya sebagai asal (asal/dasar) bagi disyariatkannya wakaf. Berdasarkan hadis ini pula Ibnu Hajar menyebutkan pendapat yang mengatakan bahwa wakaf 'Umar ini merupakan wakaf yang pertama kali terjadi dalam sejarah Islam.

Lebih lanjut, berdasarkan Undang-Undang Nomor 41 Tahun 2004 tentang Wakaf, wakaf harus memenuhi unsur-unsur wakaf yang terdiri dari sighah atau ikrar wakaf, wakif (orang yang berwakaf), mauquf (harta benda wakaf), mauquf 'alaih (penerima manfaat wakaf), nazhir (pengelola wakaf), dan jangka waktu wakaf.

Akta Ikrar Wakaf sighah, seperti dijelaskan Pasal 1 angka 3 dari UndangUndang Wakaf, merupakan pernyataan kehendak wakif yang diucapkan secara lisan dan/atau tulisan kepada nazhir untuk mewakafkan harta benda miliknya. Unsur yang kedua adalah wakif atau orang yang berwakaf. Karena wakaf merupakan akad tabarru', maka wakif disyaratkan memiliki kecakapan melakukan tindakan tabarru', yaitu sehat akalnya, dalam keadaan sadar, tidak dalam keadaan terpaksa/dipaksa, dan telah mencapai umur balig. Selain itu, dalam akad tabarru' tidak diperlukan adanya qabul dari pihak yang menerimanya (Rofiq, 1995: 494).

Unsur yang ketiga adalah harta benda wakaf (mauquf atau mauquf bihi). Menurut al-Kabisi (2003: 247), harta yang boleh diwakafkan harus memenuhi syarat-syarat tertentu, yaitu memiliki nilai guna (qimah), diketahui (ma'lum), dimiliki secara penuh oleh wakif, dan bisa berupa benda bergerak maupun tidak bergerak. Berkaitan dengan syarat yang terakhir ini, Djunaidi (2008: 44) menyatakan bahwa pada prinsipnya tidak ada mazhab fikih yang menolak dibolehkannya wakaf benda bergerak.

Unsur berikutnya adalah pemanfaatan hasil wakaf atau mauquf 'alaih. Pasal 1 poin (5) PP tentang Pelaksanaan UU Wakaf mendefinisikan mauquf 'alaih sebagai pihak yang ditunjuk untuk memperolah manfaat dari peruntukan harta 
benda wakaf sesuai pernyataan kehendak wakif yang dituangkan dalam Akta Ikrar Wakaf.

Qahaf (2006: 156) menjelaskan apa yang disebutnya sebagai tujuan wakaf, yaitu bidang-bidang yang berhak mendapatkan manfaat wakaf. Menurutnya, penerima manfaat wakaf harus berupa salah satu bidang kebaikan secara umum, tidak mengandung maksiat yang dilarang oleh syariat dan akhlak, dan tidak bertentangan dengan undang-undang yang berlaku.

Unsur wakaf yang kelima adalah pengelola wakaf atau nazhir. Menurut Sari (2006: 63), nazhir wakaf merupakan pihak yang memegang amanah melakukan perawatan, pengurusan, pengelolaan, dan pengembangan aset wakaf sesuai dengan tujuan perwakafan.

Tugas-tugas nazhir bergantung kepada bentuk wakafnya, yaitu apakah wakaf mutlaq ataukah wakaf muqayyad. Dalam wakaf mutlak, nazhir berkewajiban memelihara, mengelola, dan mengembangkan harta wakaf dengan sungguhsungguh agar dapat menghasilkan keuntungan dengan beragam investasi kemudian membagikannya kepada pihak-pihak yang berhak mendapatkannya. Sedangkan dalam wakaf muqayyad, tugas dan wewenang nazhir terbatas pada apa yang disyaratkan oleh wakif (al-Zuhaili, t.th.: 10/7688).

Dalam UU Wakaf pasal 11, tugas-tugas nazhir adalah melakukan administrasi harta benda wakaf, mengelola, dan mengembangkan harta benda wakaf sesuai dengan tujuan, fungsi, dan peruntukannya, mengawasi dan melindungi harta benda wakaf, dan melaporkan pelaksanaan tugas kepada Badan Wakaf Indonesia.

Unsur wakaf yang terakhir adalah jangka waktu wakaf. Harta benda wakaf dapat dimanfaatkan untuk selamanya atau untuk jangka waktu tertentu sesuai dengan kepentingannya. Ketentuan umum Undang-Undang Wakaf menyatakan dibolehkannya wakaf untuk jangka waktu tertentu. Wakaf dengan jangka waktu tertentu memberi peluang bagi mereka yang ingin beramal dengan tidak bermaksud melepaskan hak kepemilikannya secara menyeluruh.

\section{Sejarah SPBU Masjid Agung Semarang}

Tanah bandha wakaf Masjid Agung Semarang yang dikeloa dan dikembangkan dalam bentuk SPBU terletak di Jalan Arteri Soekarno-Hatta, Kelurahan 
Sawah Besar, Kecamatan Gayamsari. Pada mulanya, SPBU Masjid Agung Semarang merupakan unit usaha yang dimiliki oleh mantan Walikota Semarang Sutrisno Suharto.

Penelitian Husein (2006) menyebutkan bahwa lahan itu sendiri diperoleh Sutrisno Suharto dengan cara membelinya dari Tjipto Siswoyo selaku pemenang tender tukar guling bandha wakaf Masjid Agung Semarang. Persoalan ini mengemuka seiring dengan terkuaknya kontroversi tukar guling bandha wakaf Masjid Agung Semarang yang menyebabkan raibnya sebagian bandha wakaf tersebut karena dikuasai pihak lain. Lahan tempat beroperasinya SPBU milik Sutrisno Suharto ini termasuk lahan wakaf yang dikembalikan Tjipto Siswoyo kepada BKM sehingga dengan sendirinya SPBU itu harus dikembalikan kepada yang berhak memilikinya.

Proses pengembalian tanah wakaf yang sudah dalam bentuk SPBU yang dibangun oleh mantan Walikota Sutrisno Suharto ini mengalami tarik ulur yang panjang. Menurut Arifin (Wawancara: 07-05-2012), saat itu Sutrisno Suharto menawarkan tiga alternatif kepada BKM mengenai kepemilikan SPBU. Pertama, kepemilikan SPBU tetap pada Sutrisno Suharto dan dia harus membeli tanah BKM. Kedua, BKM membeli SPBU dengan harga yang disepakati. Ketiga, kepemilikan bersama antara Sutrisno Suharto dan BKM atas SPBU dengan sistem bagi hasil. Menurut Arifin, kecenderungan BKM pada saat itu adalah alternatif yang ketiga, yaitu kepemilikan bersama antara Sutrisno Suharto dengan BKM dengan sistem bagi hasil. Namun yang terjadi, menurut Arifin, adalah adanya pihak ketiga, yaitu Gubernur Jawa Tengah yang saat itu dijabat Mardiyanto, tiba-tiba membeli SPBU tersebut.

Rupanya, selain membuka wacana dengan BKM, Sutrisno Suharto juga membuka pembicaraan dengan Pengelola Masjid Agung Semarang yang didukung oleh Gubernur Jawa Tengah dan Walikota Semarang.

Menurut keterangan Hasan Toha Putra (Wawancara: 16-04-2012), pada mulanya Sutrisno Suharto meminta pihak Masjid Agung Semarang agar membeli SPBU itu seharga 3 milyar rupiah. Namun pihak Masjid Agung Semarang tidak mampu memenuhi permintaan tersebut. Sutrisno Suharto tetap bertahan dengan angka tersebut, sehingga ketika ditawar sampai 2.5 milyar rupiah pun tidak disetujuinya. 
Sampai akhirnya, menurut penjelasan Hasan, Sutrisno Suharto bertemu secara empat mata dengan Gubernur Jawa Tengah, Mardiyanto. Hasan mengaku tidak tahu apa yang dibicarakan, namun setelah itu Allah membuka hati Sutrisno Suharto sehingga ia bersedia menyerahkannya dengan harga 1.5 milyar rupiah.

Setelah ada kesepakatan itu, Badan Pengelola Masjid Agung Semarang mendapat bantuan dari Gubernur sebesar 1 milyar rupiah. Bantuan dari Gubernur Jawa Tengah, Mardiyanto, itu selanjutnya dibayarkan kepada Sutrisno Suharto. Badan Pengelola Masjid Agung Semarang berjanji akan segera melunasi kekurangannya, yaitu Rp 500.000.000,00. Namun, Sutrisno Suharto justru mengikhlaskan jumlah uang tersebut sehingga Badan Pengelola Masjid Agung Semarang tidak perlu melunasinya.

Setelah proses jual beli selesai, langkah yang ditempuh Badan Pengelola Masjid Agung Semarang berikutnya adalah mengurus balik nama SPBU tersebut. Atas pertimbangan yang sifatnya pragmatis, SPBU Masjid Agung Semarang dibalik nama atas nama Hasan Toha Putra selaku Ketua Badan Pengelola.

Sampai akhirnya disepakati tentang cara pembayaran biaya balik nama tersebut. Yaitu dengan dipotong dari hasil penjualan bensin dan solar. Maaf, saya tidak ingat persisnya. Catatannya ada pada Pak Khamad. Misalnya saja, keuntungan perliter itu 100 rupiah, maka itu dibagi dua, anggaplah $70 \%$ untuk kami dan $30 \%$ untuk Pertamina sebagai bagian dari cicilan untuk membayar biaya balik nama itu. Itu berjalan sampai lunas.

Kemudian untuk pengelolaannya, Gubernur Jawa Tengah menyerahkannya kepada Walikota Semarang, yaitu Bapak Sukawi Sutarip. Selanjutnya, Walikota Semarang menunjuk Badan Pengelola Masjid Agung Semarang untuk menjalankan operasional bisnis SPBU dan berkewajiban mengembangkannya.

Mengomentari sejarah berdirinya SPBU MAS seperti di atas, Husein (2006) menyatakan bahwa keberadaan SPBU sebagai salah satu bentuk pemberdayaan bandha wakaf MAS lebih tepat disebut sebagai "kecelakaan" yang menguntungkan. Husein beralasan bahwa tanah wakaf tersebut sebelumnya merupakan tanah kosong yang tidak produktif kemudian dikelola dengan tanpa rencana menjadi tanah wakaf produktif yang menghasilkan keuntungan materiil yang signifikan. 


\section{Pengelolaan SPBU Masjid Agung Semarang}

Saat ini, SPBU MAS melayani penjualan BBM jenis pertamax, premium, dan bio solar, membuka layanan cuci dan salon mobil, layanan ATM, fasilitas pengisian angin dan air radiator, terapi bugar dan klinikita Masjid Agung Semarang, dan memiliki minimarket.

Fasilitas SPBU MAS telah memenuhi standar layanan dan standar bangunan fisik perkantoran dan bangunan kanopi tempat penjualan SPBU yang layak. Dari segi bangunan fisik, SPBU MAS memiliki bangunan utama yang terdiri dari dua lantai. Lantai bawah dimanfaatkan untuk kantor administrasi SPBU, kantor manajer, kantor karyawan, minimarket, terapi bugar dan klinikita Masjid Agung Semarang, layanan ATM Mandiri dan ATM BRI, dan warung makan. Di sebelah kanan bangunan utama, terdapat ruang usaha yang disewakan untuk usaha cuci dan salon mobil.

Lantai atas terdiri dari ruang staf dan karyawan SPBU, tempat wudhu, dan mushalla yang cukup luas dan bersih. Dari segi bangunan, SPBU MAS memiliki dua kanopi penjualan BBM dan empat dispenser. Masing-masing dispenser memiliki dua nozzle. Kanopi pertama, yang merupakan kanopi utama dan digunakan untuk melayani pembeli dengan menggunakan kendaraan roda empat, memiliki tiga dispenser dan enam nozzle. Dispenser pertama yang terletak paling dekat dengan jalan raya memiliki dua nozzle, yaitu nozzle 1 dan nozzle 2 yang digunakan untuk menjual BBM jenis premium. Dispenser kedua yang terletak di tengah memiliki dua nozzle, yaitu nozzle 3 untuk menjual BBM jenis premium dan nozzle 4 untuk menjual BBM jenis pertamax. Dispenser ketiga terdiri dari dua nozzle, yaitu nozzle 5 dan nozzle 6 yang digunakan untuk menjual BBM jenis bio solar.

Kanopi kedua letaknya terpisah dengan kanopi utama hanya memiliki satu dispenser dengan dua nozzle, yaitu nozzle 7 dan nozzle 8. Keduanya digunakan untuk menjual BBM jenis premium dan khusus melayani pembeli dengan kendaraan roa dua atau motor.

Badan Pengelola Masjid Agung Semarang mengawali pengelolaan SPBU 44.501.18 ini pada bulan Januari 2005. Pada saat itu, Badan Pengelola menunjuk Wahid Ahmad sebagai manajer. Sebelum menjadi manajer SPBU, Wahid Ahmad merupakan salah satu pengurus Badan Pengelola dan telah melakukan training 
atau magang di SPBU tersebut selama dua bulan, yaitu bulan November dan Desember 2004. Maksud dari training tersebut adalah untuk mempelajari secara langsung operasional bisnis SPBU dan mempersiapkan langkah-langkah peralihan hak dari pemilik lama, yaitu Sutrisno Suharto dan Susanti Dian Safitri, kepada pemilik baru, yaitu Badan Pengelola Masjid Agung Semarang (Wawancara dengan Wahid Ahmad: 24-05-2012).

Setelah secara resmi menerima hak kelola SPBU tersebut, Badan Pengelola segera melakukan pembenahan agar sesuai dengan visi Masjid Agung Semarang. Selain menempatkan Wahid Ahmad pada posisi manajer, Badan Pengelola merekrut beberapa karyawan baru untuk penyegaran. Sebagian karyawan lama tetap dipertahankan dan sebagian lainnya digantikan dengan tenagatenaga baru yang lebih produktif.

Pembenahan juga dilakukan pada fisik SPBU seperti perbaikan sarana dan prasarana. Sebagai salah satu bentuk sosialisasi atas perubahan kepemilikan tersebut, pada bagian depan kanopi pompa bensin SPBU dipasang tulisan yang berbunyi "Selamat datang di SPBU Masjid Agung Semarang" dan tulisan lain berbunyi "Celakalah bagi orang-orang yang berbuat curang".

Secara sepintas, setiap orang yang melewati jalan depan SPBU MAS dapat membaca dan mengetahui status SPBU tersebut sehingga diharapkan dapat menarik minat calon konsumen agar membeli BBM di SPBU tersebut.

Saat ini, kondisi SPBU Masjid Agung Semarang telah dipercaya oleh masyarakat sebagai salah satu SPBU yang terjamin kualitasnya dan juga tera atau ukurannya. Secara umum, masyarakat Kota Semarang juga sudah mengetahui keberadaan dan kepemilikan SPBU tersebut. Tidak dipungkiri juga adanya sebagian konsumen yang sengaja membeli BBM di SPBU MAS karena alasan yang sifatnya ideologis, yaitu membeli BBM sambil beramal dengan turut memakmurkan Masjid Agung Semarang.

Kepercayaan konsumen akan kualitas BBM, akurasi tera atau ukuran, layanan yang baik, dan kepemilikan SPBU oleh sebuah masjid merupakan modal yang kuat bagi kelangsungan usaha tersebut. Apabila kepercayaan masyarakat tersebut dapat terjaga dengan baik, dapat diprediksi minat konumen atau calon konsumen untuk membeli BBM di SPBU tersebut terus meningkat. Apalagi kondisi saat ini, persaingan bisnis SPBU semakin ketat dan masyarakat semakin cerdas dalam memilih barang yang akan dibeli. 
Menurut Wahid Ahmad (Wawancara: 24-05-2012), rata-rata penjualan atau omset yang berhasil dijual SPBU Masjid Agung Semarang dari seluruh bentuk BBM yang ditawarkan adalah 20.000 liter perhari. Pada masa kepemimpinannya dari tahun 2005 hingga awal 2012, rekor penjualan paling tinggi dalam satu hari bagi seluruh bentuk BBM adalah 22.000 liter.

Berdasarkan volume penjualan tersebut, menurut Fery Pujiyanto (Wawancara: 28-02-2013), pendapatan bersih yang diperoleh dari pengelolaan SPBU Masjid Agung Semarang rata-rata berada pada kisaran 35 juta hingga 40 juta rupiah perbulan. Angka tersebut merupakan nominal yang diserahkan manajemen SPBU Masjid Agung Semarang kepada Badan Pengelola Masjid Agung Semarang setelah dikurangi biaya-biaya operasional seperti gaji karyawan, listrik, dan lain-lain.

\section{Mendapatkan Sertifikat Pasti Pas}

Ketika masih bernaung di bawah UU No 22 Tahun 1971, selain sektor hulu, Pertamina merupakan perusahaan monopoli dalam mengelola usaha minyak dan gas bumi di Indonesia. Ketika era globalisasi dimulai, UU No 22 Tahun 1971 diganti dengan UU Migas No 22 Tahun 2001. Berdasarkan UU ini, Pertamina bukan lagi satu-satunya pemain dalam sektor hilir usaha di bidang migas, melainkan hanya salah satu pelaku bisnis dalam bidang migas yang bersaing dengan perusahaan-perusahaan lain, baik domestik maupun asing, yang bergerak dalam bidang tersebut.

Untuk merespon perubahan tersebut, Pertamina dituntut melakukan berbagai transformasi agar dapat menjadi perusahaan yang mampu bersaing dengan perusahaan-perusahaan asing. Di antara kebijakan yang diambil Pertamina adalah mengenalkan dua macam SPBU, yaitu SPBU Pertamina biasa (Non Pasti Pas) dan SPBU Pasti Pas.

SPBU Pasti Pas merupakan upaya dari Pertamina untuk membenahi industri ritel BBM. Untuk mendukung upaya ini, Pertamina dalam Depary (2010: 22) meluncurkan program yang dikenal dengan Program Pertamina Way yang merupakan program pembenahan manajemen dan pelayanan SPBU yang terdiri dari 5 elemen, yaitu pelayanan staf yang terlatih, jaminan kualitas dan kuantitas, peralatan yang terawat dengan baik, format fisik yang konsisten, 
dan penawaran produk dan pelayanan yang baik. SPBU yang telah menerapkan SPBU Pertamina Way dinilai telah memenuhi jaminan pelayanan terbaik sesuai standar internasional dan selanjutnya disertifikasi menjadi SPBU Pasti Pas. Pasti Pas adalah SPBU yang telah mendapatkan sertifikat Pasti Pas dari auditor independen dengan jaminan pelayanan terbaik yang memenuhi standar kelas dunia. Konsumen akan mendapatkan kualitas dan kuantitas BBM yang terjamin, pelayanan yang ramah, serta fasilitas yang nyaman.

Sedangkan SPBU yang belum mengikuti Program Pertamina Way disebut dengan SPBU biasa atau SPBU Non Pasti Pas. Perbedaan antara SPBU Pasti Pas dengan SPBU biasa dapat dilihat dari segi fisik, non fisik, maupun kebijakan pertamina terhadap kedua jenis SPBU tersebut. Secara fisik, SPBU Pasti Pas berbeda dengan SPBU biasa, misalnya dari segi bentuk bangunan, kondisi peralatan, maupun pelayanan terhadap konsumen. Secara non fisik atau yang tidak dapat dilihat, SPBU Pasti Pas menerapkan standar yang lebih baik dalam hal kepercayaan konsumen, menjaga citra SPBU, kepastian kalibrasi pompa, dan lainnya.

Merespon perubahan kebijakan dari Pertamina tersebut, SPBU Masjid Agung Semarang segera berbenah untuk mengikuti perkembangan yang terjadi pada dunia bisnis SPBU. Dapat diprediksi bahwa pada saat akan membeli BBM, konsumen akan lebih memilih SPBU yang telah mendapatkan sertifikat Pasti Pas daripada SPBU biasa karena melihat beberapa keunggulan yang terdapat pada SPBU Pasti Pas.

Pertimbangan lain bagi SPBU Masjid Agung Semarang untuk mendapatkan sertifikat Pasti Pas karena adanya kebijiakan Pertamina yang lebih memihak pada SPBU Pasti Pas, terutama dalam hal pembagian margin keuntungan. Pertamina memberikan margin keuntungan yang lebih besar bagi SPBU Pasti Pas daripada keuntungan yang diberikan kepada SPBU biasa. Hal ini diantaranya dimaksudkan agar seluruh SPBU yang menjadi mitra Pertamina dalam bidang distribusi BBM dapat menerapkan standar yang diakui secara internasional.

Jika dilihat dari segi kepemilikan, SPBU MAS merupakan SPBU yang dimiliki dan dikelola oleh pihak swasta, yaitu Badan Pengelola Masjid Agung Semarang. Berdasarkan hal ini, SPBU MAS termasuk dalam kategori SPBU DODO atau Dealer Owned Dealer Operated. 
Sedangkan jika dilihat dari volume penjualan, SPBU Masjid Agung Semarang tergolong pada SPBU TIPE C karena rata-rata omset penjualan harian SPBU Masjid Agung Semarang adalah 20 KL BBM.

SPBU Pertamina Pasti Pas juga bertingkat, sesuai dengan standar kinerja SPBU itu sendiri dan berdasarkan standar yang telah ditetapkan Pertamina, yaitu Pasti Pas Silver, Pasti Pas Gold, dan Pasti Pas Diamond. Dari segi ini, SPBU Masjid Agung Semarang termasuk dalam kategori SPBU Pasti Pas Silver (Wawancara: Wahid Ahmad, 24 Mei 2012)

Selain keuntungan finansial, SPBU Masjid Agung Semarang yang telah memiliki sertifikat Pasti Pas, akan mendapatkan banyak keuntungan, seperti peningkatan kepercayaan, kepuasan, dan kesetiaan pelanggan, prioritas dalam distribusi BBM, training bagi pekerja SPBU, diikutkan dalam programprogram marketing Pertamina Way, diberikan berbagai aksesoris Pertamina Way (seperti seragam, kantong uang, dan topi), dan menjadi bagian dari Pasti Pas Community (Depary, 2010: 31).

Berbagai keunggulan yang dimiliki SPBU Pasti Pas telah berhasil mendorong para pengusaha SPBU untuk menambah investasi baru guna menyesuaikan dengan kebijakan tersebut. Investasi tersebut digunakan untuk menyediakan fasilitas dan layanan tambahan agar dapat masuk dalam kriteria SPBU Pasti Pas. Investasi yang dibutuhkan untuk merombak SPBU Masjid Agung Semarang dari SPBU biasa menjadi SPBU Pasti Pas tergolong tidak sedikit. Biaya tersebut digunakan untuk memenuhi syarat-syarat yang ditetapkan Pertamina bagi SPBU yang bermaksud mengajukan sertifikat Pasti Pas seperti persyaratan yang berkaitan dengan fisik dan kelengkapan administrasi. Biaya paling besar dialokasikan untuk merubah tampilan fisik SPBU, terutama kanopi pompa bensin yang harus disesuaikan dengan standar Pertamina.

Di antara dampak dari perubahan status SPBU Masjid Agung Semarang adalah dihilangkannya tulisan yang sebelumnya tertera pada kanopi pompa bensin yang berisikan ucapan selamat datang kepada konsumen. Setelah mendapatkan sertifikat Pasti Pas dan keharusan mengikuti standar fisik yang ditetapkan Pertamina, tulisan yang menjelaskan kepemilikan SPBU dan sejenisnya harus dihilangkan.

Besarnya nilai investasi dan keharusan mengikuti persyaratan seperti tersebut di atas dirasa sebanding dengan keuntungan yang hendak diraih. 
Selain mendapatkan margin keuntungan yang lebih besar dari Pertamina, SPBU Pasti Pas juga mampu mendongkrak omset penjualan karena saat ini sebagian besar konsumen sudah termotivasi untuk mengisi BBM di SPBU yang telah mendapatkan sertifikat Pasti Pas. Dengan meningkatnya jumlah konsumen yang membeli BBM di SPBU tersebut, diharapkan juga turut mendongkrak pendapatan SPBU melalui unit-unit usaha lainnya, seperti minimarket, restoran, dan jasa toilet.

SPBU Masjid Agung Semarang telah berhasil mendapatkan sertifikat Pasti Pas sejak bulan Mei 2011. Berdasarkan peringkat kinerjanya, SPBU Masjid Agung Semarang termasuk dalam kategori SPBU Pasti Pas Silver dan berhak mendapatkan margin keuntungan dari penjualan premium dan solar sebesar Rp 205,00 perliter dan dari penjualan BBM jenis pertamax sebesar Rp 325,00 perliter.

Menurut Fery Pujiyanto (Wawancara: 28-02-2013), agar dapat mempertahankan peringkat SPBU Pasti Pas Silver, manajemen SPBU harus berusaha menjaga mutu atau kualitas layanan dan diaudit oleh auditor independen setiap bulan. Apabila berhasil mempertahankan peringkat tersebut dan dinyatakan lulus pada saat audit setiap bulan selama tiga kali berturut-turut, maka SPBU Masjid Agung Semarang berhak untuk mengajukan permohonan kepada Pertamina untuk mendapatkan peringkat SPBU Pasti Pas yang lebih tinggi, yaitu peringkat gold. Manajemen SPBU Masjid Agung Semarang saat ini sedang berusaha mempertahankan standar administrasi dan layanan SPBU Pasti Pas Silver dan pada saat yang sama sedang berusaha meningkatkan kinerjanya agar dapat mendapatkan peringkat yang lebih tinggi. Menurut Fery Pujiyanto (Wawancara: 28-02-2013), kendala utama bagi SPBU MAS untuk mendapatkan peringkat gold terletak pada tingkat penjualan BBM khusus yang tidak mampu memenuhi volume yang ditetapkan Pertamina.

\section{Peluang Usaha SPBU bagi Lembaga Wakaf}

Hingga saat ini, bisnis SPBU masih menjadi bisnis yang menjanjikan dan diminati banyak investor. Meskipun tingkat persaingan semakin tajam, beberapa SPBU yang berdiri di atas lahan strategis dan memberikan pelayanan yang baik masih tetap eksis dan semakin berkembang seiring dengan bertambahnya jumlah kendaraan bermotor setiap harinya. 
Bagi lembaga wakaf, bisnis SPBU merupakan salah satu alternatif bisnis yang menarik, khususnya bagi aset-aset wakaf berupa tanah yang terletak di kawasan strategis. Tingkat keuntungan yang cukup tinggi dan risiko kerugian yang kecil menjadikan bisnis SPBU sebagai model atau percontohan bagi pemberdayaan wakaf produktif.

Meskipun bisnis SPBU termasuk jenis usaha yang cocok bagi pengembangan aset wakaf produktif, tidak banyak lembaga wakaf yang mampu mewujudkannya. Hal ini disebabkan oleh syarat-syarat pendirian bisnis SPBU yang cukup berat, khususnya berkaitan dengan ketersediaan lahan strategis dan modal yang cukup besar. Lembaga wakaf yang berminat memasuki bisnis ini harus menyediakan tempat usaha yang cukup luas, terletak di pinggir jalan besar, banyak dilalui kendaraan, dan persaingan ritel bensin di sekitar lokasi tersebut belum tinggi.

Terkait dengan kerjasama mendirikan SPBU ini, lembaga wakaf juga harus mempersiapkan royalty fee dan dana deposit. Royalty fee merupakan dana yang diberikan dari pembagian menurut prosentase keuntungan yang besarnya ditentutan oleh lokasi dan hasil negosiasi atau kesepakatan bersama (Suhardo, 2008: 66). Setiap lima tahun sekali, Pertamina akan mengevaluasi SPBU yang bersangkutan dan menarik royalty fee yang telah disepakati. Jika lokasi SPBU cukup luas dan lokasinya strategis, lembaga wakaf sebagai pemilik SPBU dibolehkan membuka unit-unit usaha lain di sekitar lokasi SPBU. Hal itu itu dimaksudkan agar dapat menarik minat konsumen untuk mengisi BBM di SPBU tersebut dan juga untuk meningkatkan penghasilan SPBU. Di antara jenis-jenis usaha yang dapat dibuka di sekitar SPBU adalah Store Pertamina Bright atau toko ritel, Pertamina Speed Service Station atau gerai pelayanan bengkel cepat, cuci motor dan mobil, restoran dan aneka makanan, dan stand ATM.

Selain unit-unit usaha tersebut, fasilitas pendukung yang selalu ada pada setiap SPBU adalah mushalla, toilet atau WC, dan area istirahat. Beberapa SPBU memberikan fasilitas dan layanan yang sangat baik dan memanjakan pelanggan sebagai bagian dari strategi marketing agar dapat menanamkan loyalitas konsumen pada SPBU tersebut. Berbagai fasilitas dan layanan tersebut tentu saja menguntungkan konsumen sehingga dengan sendirinya mereka akan memilih mengisi BBM pada SPBU yang menawarkan layanan terbaik bagi mereka. Dengan demikian, apabila ada SPBU yang tidak mau berbenah, tidak 
memberikan layanan yang dikenal dengan Pasti Pas, tidak menyediakan fasilitasfasilitas yang memuaskan konsumen, apalagi seringkali merugikan konsumen, dapat dipastikan akan sepi dari pembeli, mengingat persaingan bisnis SPBU yang semakin ketat dan semakin banyaknya jumlah SPBU yang dapat dijumpai pengendara.

\section{Kesimpulan}

Berdasarkan uraian di atas, penelitian ini sampai pada kesimpulan bahwa SPBU Masjid Agung Semarang telah berhasil mewujudkan model pengelolaan dan pengembangan aset wakaf secara produktif. SPBU Masjid Agung Semarang telah berhasil memberikan kontribusi yang signifikan bagi Masjid Agung Semarang dan telah berkembang sesuai dengan tuntutan bisnis karena telah mendapatkan sertifikat Pasti Pas. Dari segi layanan, SPBU Masjid Agung Semarang telah berhasil mewujudkan kinerja unit usaha yang dapat memuaskan konsumen karena menyediakan bahan bakar minyak yang diperlukan oleh pengendara pada umumnya. Unit-unit usaha maupun fasilitas yang melekat pada SPBU Masjid Agung Semarang juga sudah lengkap, seperti mushalla, toilet, pengisian air dan angin, ATM, tempat istirahat, minimarket, klinik, usaha cuci mobil, dan penjualan oli. Beragamnya layanan dan fasilitas yang disediakan cukup memberikan rasa optimisme bagi pengelola lembaga wakaf untuk mengadopsi model yang sudah dikembangkan oleh pengelola bandha wakaf tersebut.

\section{Daftar Pustaka}

Al-'Asqalani, Ahmad Ibn 'Ali Ibn Hajar. 2000. Fath al-Bari Syarh Sahih Bukhari. Bairut: Dar al-Kutub al-'Ilmiyyah.

Al-Zuhaili, Wahbah. 1997. al-Fiqh al-Islami wa Adillatuhu. Beirut: Dar al-Fikr. cetakan IV.

BKM. Data Kekayaan BKM Tahun 2005. Laporan tidak dipublikasikan oleh Badan Kesejahteraan Masjid Kota Semarang.

Depary, Astrid Orsini. 2010. Analisis Faktor-Faktor yang Mempengaruhi Kinerja Pemasaran di Stasiun Pengisian Bahan Bakar untuk Umum (SPBU) di 
Semarang. Tesis tidak dipublikasikan. Program Pascasarjana Magister Manajemen Universitas Diponegoro.

Djunaidi, Ahmad. dkk. 2008. Strategi Pengembangan Wakaf Tunai di Indonesia.

Jakarta: Direktorat Pengembangan Zakat dan Wakaf Depag RI

Emir, 2012. Metodologi Penelitian Kualitatif: Analisis Data. Jakarta: PT Raja Grafindo Persada.

Hammad, Nazih. 1995. Mu'jam al-Mustalahat al-Iqtisadiyyah fi Lugati al-Fuqaha.

Virginia: al-Ma'had al-'Alami li al-Fikri al-Islami

Husein, M. 2006. Pengelolaan Tanah Wakaf Produktif (Studi Kasus Tanah Wakaf Dalam Bentuk Stasiun Pengisian Bahan Bakar Umum (SPBU) di Kelurahan Sawah Besar Kecamatan Gayamsari Kota Semarang). Skripsi tidak dipublikasikan. Jurusan Ahwal Syahsiyah. Fak. Syariah IAIN Walisongo.

Manzur, Ibn. t.t. Lisan al- 'Arab. Dar al-Ma'arif.

Putra, Nusa. 2013. Metode Penelitian Kualitatif Manajemen. Jakarta: PT Raja Grafindo Persada.

Qahaf, Munzir. 2006. al-Waqfal-Islami: Tatawwuruhu, Idaratuhu, Tanmiyyatuhu, Damaskus: Dar al-Fikr.

Rofiq, Ahmad. 1995. Hukum Islam di Indonesia. Jakarta: Rajawali Press.

Sari, Elsi Kartika. 2006. Pengantar Hukum Zakat dan Wakaf. Jakarta: Penerbit PT Grafindo.

Sedarmayanti, 2007. Good Governance (Kepemerintahan yang Baik) dan Good Corporate Governance (Tata Kelola Perusahaan yang Baik). Bandung: Mandar Maju.

Suhardo, dkk. 2008. Model Pengembangan Wakaf Produktif. Jakarta: Departemen Agama Direktorat Jenderal Bimbingan Masyarakat Islam Direktorat Pemberdayaan Wakaf.

Yusuf, Agus Fathuddin. 2000. Melacak Banda Masjid yang Hilang. Semarang: Aneka Ilmu. 


\section{Wawancara}

Wawancara dengan Arifin, Anggota Badan Kesejahteraan Masjid Agung Semarang, tanggal 7 Mei 2013.

Wawancara dengan Fery Pujiyanto, Manajer SPBU Masjid Agung Semarang, tanggal 28 Februari 2013.

Wawancara dengan Hasan Toha Putra, Ketua Badan Pengelola Masjid Agung Semarang, tanggal 16 April 2012.

Wawancara dengan Wahid ahmad, Anggota Badan Pengelola Masjid Agung Semarang, tanggal 24 Mei 2012. 